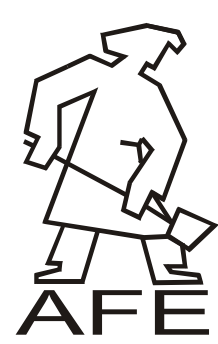

\title{
Influence of Blowing of Argon on the Cleanness of Steel
}

\author{
A. Pribulová \\ Department of Iron Metallurgy and Foundry, Faculty of Metallurgy, Technical University in Košice , Park Komenského 14, \\ 04001 Košice, Slovakia \\ Corresponding author. E-mail address: alena.pribulova@tuke.sk
}

Received 16.04.2012; accepted in revised form 02.07.2012

\begin{abstract}
The mechanical properties of steel components are controlled by the chemical composition and mechanical treatment to which the steel is submitted. Non-metallic inclusions have a very high influence on the steel quality but secondary metallurgy enables to reduce their content in the steel. Possibilities of secondary metallurgy are relatively extensive but financial situation in Slovak foundries does not enable to make investments in secondary metallurgy in the near future. Accessible means for influencing of steel quality is injection of an inert gas .

Main goal of experiments described in the article was verify the influence of blowing of argon into the steel in an electric induction furnace on its cleanness. Duration and flow-rate of argon blowing have a very clearly influence on the final content of non-metallic inclusions. Minimum time of argon blowing necessary for reducing of content of non-metallic inclusions in one tonne electric induction furnace was more than 6 minutes and recommended argon flow rate was 10 litters per minute.
\end{abstract}

Keywords: Castings Defects, Metallography, Non-Metallic Inclusions, Argon Blowing, Argon-Flow Rate

\section{Introduction}

Development of present technologies makes demands on steel quality and stability of functional properties. It is not possible to reach these requirements in existing melting aggregates and then the additional measures for improvement of steel quality are necessary.

The mechanical properties of steel components are controlled by the chemical composition and mechanical treatment to which the steel is submitted $[1,2]$.

One of the biggest causes of a decrease in steel quality is nonmetallic inclusions. Every kind of steel has nonmetallic inclusions of some sort, at the very least, in small quantities [3 7]. Despite the proportionally small volume, such inclusions influence the mechanical properties [8], the work ability, the machinability and the superficial finish of the steel products.

Nonmetallic inclusions are formed mostly in the liquid steel deoxidation phase in a ladle furnace. When these particles are not captured by the slag, they are found in solidified steel, deteriorate its mechanical properties $[9,10]$.

Financial situation in Slovak foundry industry doesn't enable to make investment in secondary metallurgy in the near future. Accessible means for influencing of steel quality is for example injection (blowing) of an inert gas [11].

The injection of inert gases into molten metal is a procedure that is usually done to make the metal's composition and temperature uniform over the volume of the ladle and to remove non-metallic inclusions and dissolved impurities [12,13]

Non-metallic particles that are poorly wetted by the melt may be captured by the surface of gas bubbles and rise along with the bubbles to the free surface. Solid inclusions of alumina and silicon that are poorly wetted by liquid steel can be affectively removed together with gas bubbles. The rate of removal of nonmetallic inclusions of different sizes from a melt is significantly influenced their flotation by bubbles of the inert gas [14, 15]

The main goal of experiments was determine the influence of volume and duration of inert gas blowing in to the steel in electric 
induction furnace on the content of non-metallic inclusions in the liquid steel.

\section{Description of experiments}

The experiments were realised in the Slovak foundry that produces cast iron and steel castings which are used in different industry areas.

Melting of steel and injection of argon were made in one tone electric induction furnace with next parameters:

type of furnace : ISTOL

furnace capacity : $1200 \mathrm{~kg}$

weight of molten metal : $1000 \mathrm{~kg}$

furnace input : $1200 \mathrm{~kW}$

frequency : $600 \mathrm{~Hz}$

melting time : 45 minutes

specific consumption : $630 \mathrm{kWh} /$ hour.

Injection of argon was realized directly in to the electric induction furnace. Gas diffuser was installed in to the lining, Fig.1, and it ensures constant flow rate of gas via molten metal. Usually 10 litters per minute of argon is blowing. The flow rate can be reduced if temperature is rising and bubbling is more intensive.

Samples of metal were taken directly from the melted metal from the metal surface after slagging-off. They were prepared for metallographic analyse and they were analysed, firstly in the optical microscope with image analyse, for verification of the quantity of inclusions per unit of area. The analysed area was approximately 100 $\mathrm{mm}^{2}$.

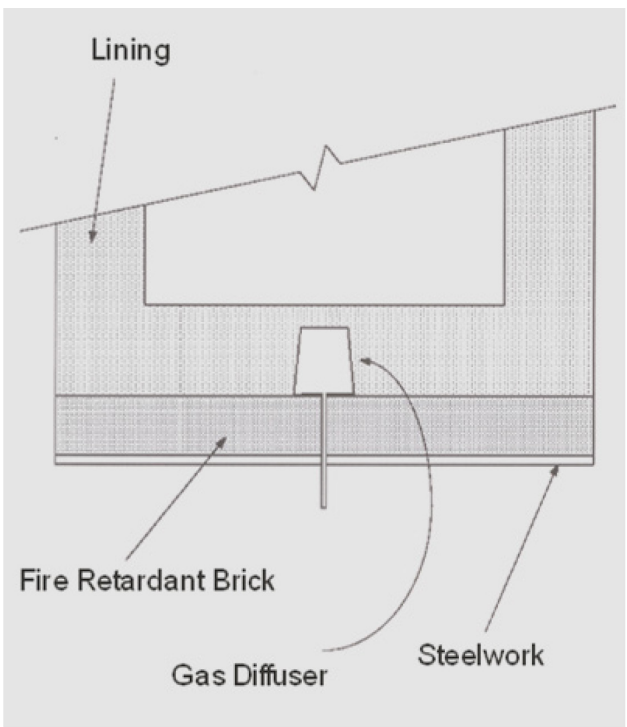

Fig. 1 Gas diffuser installed into the bottom of electric induction furnace

Table 1.

\begin{tabular}{|c|c|c|c|c|c|}
\hline $\begin{array}{l}\text { Sample } \\
\text { No. }\end{array}$ & $\begin{array}{l}\text { Duration of } \mathrm{Ar} \\
\text { blowing, min. }\end{array}$ & Period of melt & $\begin{array}{c}\text { Area fraction of } \\
\text { the NI, } \%\end{array}$ & $\begin{array}{c}\text { Ar flow rate, } \\
1 / \mathrm{min} .\end{array}$ & $\begin{array}{c}\text { Volume of } \mathrm{Ar} \\
\text { blowing, } 1\end{array}$ \\
\hline A0 & - & after melting down of steel & 0.19 & - & - \\
\hline A5 & - & 5 minutes after melting down & 0.44 & - & - \\
\hline A7 & - & 7 minutes after melting down & 0.37 & - & - \\
\hline$A_{L}$ & - & from the ladle & 0.23 & - & - \\
\hline B0 & - & after melting down & 0.19 & - & - \\
\hline $\mathrm{B}_{\mathrm{E}}$ & 2 & end of the melt & 0.24 & 6 & 12 \\
\hline $\mathrm{C} 0$ & - & after melting down & 0.21 & - & - \\
\hline $\mathrm{C}_{\mathrm{E}}$ & 2 & end of the melt & 0.47 & 10 & 20 \\
\hline D0 & - & after melting down & 0.20 & - & - \\
\hline$D_{E}$ & 4 & end of the melt & 0.43 & 10 & 40 \\
\hline E0 & - & after melting down & 0.19 & - & - \\
\hline$E_{E}$ & 6 & end of the melt & 0.31 & 10 & 60 \\
\hline F0 & - & after melting down & 0.18 & - & - \\
\hline $\mathrm{F}_{\mathrm{E}}$ & 8 & end of the melt & 0.15 & 10 & 80 \\
\hline G0 & - & after melting down & 0.16 & - & - \\
\hline $\mathrm{G}_{\mathrm{E}}$ & 10 & end of the melt & 0.14 & 10 & 100 \\
\hline $\mathrm{H} 0$ & - & after melting down & 0.19 & - & 0 \\
\hline $\mathrm{H}_{\mathrm{E}}$ & 10 & end of the melt & 0.12 & 10 & 100 \\
\hline J0 & - & after melting down & 0.19 & - & - \\
\hline $\mathrm{J} 2$ & 2 & 2 minutes after melting down & 0.25 & 4 & 8 \\
\hline $\mathrm{J} 4$ & 4 & 4 minutes after melting down & 0.65 & 4 & 16 \\
\hline $\mathrm{J} 6$ & 6 & 6 minutes after melting down & 0.21 & 10 & 36 \\
\hline $\mathrm{J} 8$ & 8 & end of the melt & 0.18 & 10 & 56 \\
\hline
\end{tabular}

NI - non-metallic inclusions 


\section{Achieved results and their analyse}

Ten melts of steel were made in one tone electric induction furnace. How it was mentioned every melt took for 45 minute. Table 1 shows the period of melt in which the samples were taken, volume of argon blowing, argon flow rate and content of nonmetallic inclusions. Samples A were taken from the steel without argon blowing. It is given in Table 1 that the samples were taken from the steel after melting down (A0) and then after 5 (A5) and 7 (A7) minutes after melting down and last sample was taken from the ladle $\left(\mathrm{A}_{\mathrm{L}}\right)$.

Samples B were taken after melting down (B0) and at the end of melting. The blowing of argon took for two minutes and argon flow rate was 6 litters per minute. Samples C, D, E and F were taken from melted steel before and after argon blowing at the end of melt and the flow rate of argon was 10 litters per minute. Samples $\mathrm{G}$ and $\mathrm{H}$ were taken again from melted steel before and after argon blowing, argon was blowing for 10 minutes with flow rate 10 litters per minute. Samples J were taken after melting down and then after next two, four, six and eight minutes of blowing. First four minutes the argon flow rate was 4 litters per minute and next four minutes it was 10 litters per minute.

Fig. 2 shows the course of steel cleanness in the dependence on the period of melt with and without argon blowing. In the both cases after $4^{\text {th }}$ and $5^{\text {th }}$ minute after melting down the content of non metallic inclusions has increased very expressively. It is caused of

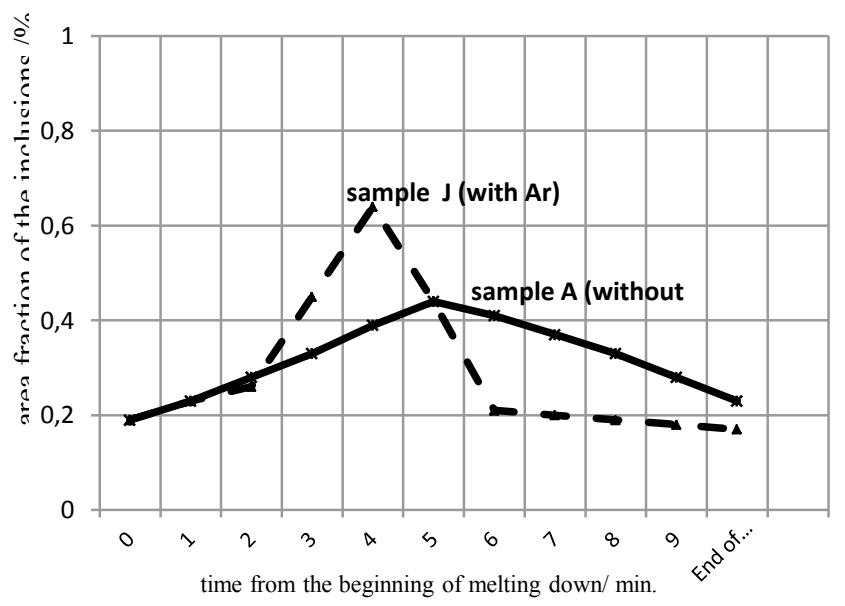

Fig. 2. Evolution of quantity of non-metallic inclusion in sample without and with Ar blowing

metallurgical processes slipping in the molten metal. After then the content of non-metallic inclusions fell down

At the end of melt without argon blowing the content of nonmetallic inclusions increased about $17.3 \%$ and with argon blowing (argon was blowing for 8 minutes and volume of argon was 56 litters) the content of non-metallic inclusions dropped about 5.5\%. Duration of argon blowing has a very important role for content of non-metallic inclusions. Melts B,C,D,E were with argon blowing. The flow rate of argon was 6 or 10 litters per minute for all melts and duration of blowing was 2, 4 and 6 minutes. In all melts occurs to increasing of content of non-metallic inclusions. Marked fall of non-metallic inclusions set in by argon flow 10 litters per minute after 8 and 10 minutes of argon blowing (the content of nonmetallic inclusions dropped about $16 \%$ in sample $\mathrm{F}$, about $12.5 \%$ in sample $\mathrm{G}$ and about $58 \%$ in sample H. Fig.3 shows the nonmetallic inclusions content in the samples from melts in the depending of duration of argon blowing.

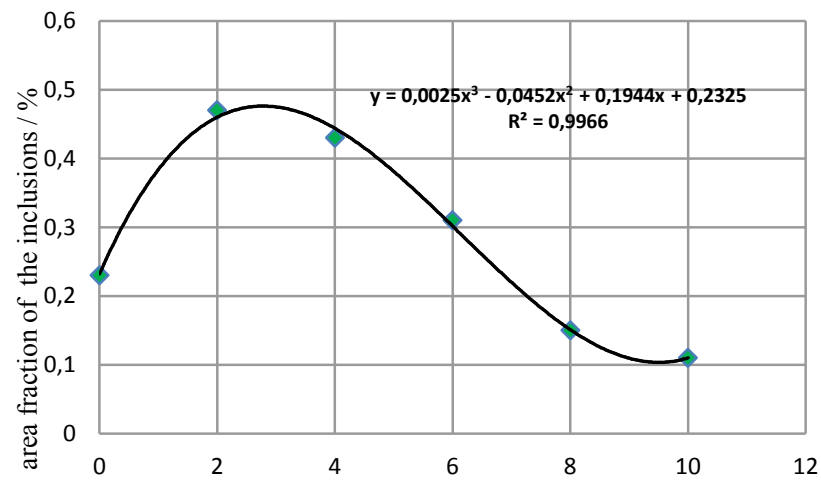

duration of Ar blowing/ min.

Fig. 3. Influence of duration of Ar blowing on content of non-metallic inclusions

A curve on the Fig. 3 was construed from samples A0, $C_{E}, D_{E}$, $E_{E}, F_{E}$ and $\mathrm{H}_{\mathrm{E}}$. All samples were taken from the melts with flow rate of argon 101 per minute. The curve has a polynomial character (polynom of the second degree) and because $\mathrm{R}^{2}=$ 0.9966 it is possible to describe the content of non-metallic inclusions in dependence on duration of argon blowing with an equation:

$y=0,0025 \cdot x^{3}-0,0452 \cdot x^{2}+0,1944 \cdot x+0,2325$

$\mathrm{y}-$ content of non-metallic inclusions, $\%$

$\mathrm{x}$ - duration of argon blowing (by flow rate of argon 10 litters per minute

It is clear from the curve that drop in content of non-metallic inclusions in comparison with content on the beginning of melt was after 7 minutes of argon blowing.

\section{Conclusions}

Main goals of experiments described in this article was verify the influence of blowing of argon into the molten steel on its cleanness which is given of non-metallic inclusions content. It was made 10 melts (one without and 9 with argon blowing) in the electric induction furnace.

Next conclusions follow from the achieved results:

- Course of non-metallic inclusions in molten steel during the melt in the electric induction furnace is a very similar without and with argon blowing. 
- In both cases in the first period of melt the content of nonmetallic inclusions has increased, after then the content of nonmetallic inclusions has dropped very clearly.

- Fall in the non-metallic inclusions content in the steel without argon blowing can be caused of stirring up of steel that is very clearly in electric induction furnace because of whirling current.

- Duration of argon blowing into the steel has had a very significant influence on the final content of non-metallic inclusions.

- Short time of argon blowing or small volume of argon (melts C, $\mathrm{D}, \mathrm{E})$ can cause that final content of inclusions can be higher than on the beginning of melting.

- Minimum time of argon blowing necessary for reducing of content of non-metallic inclusion in one tonne electric induction furnace was 7 minutes and recommended argon flow rate is 10 litters per minute.

\section{Acknowledgements}

This work was supported by the Scientific Grant Agency of the Ministry of Education of the Slovak Republic No.VEGA 1/0836/12.

\section{References}

[1] Seilerová, K., \& Mihok, L', Domovec, M. \& Balco, K. (2004). Influence of clarificationon the steel cleanliness. Acta Metallurgica Slovaca 10 (1), pp. 36-41 (Slovak).

[2] Carlos, J., Pires, S. \& Garcia, A.(2003). Study of the nature of non-metallic inclusions in samples of aluminium and silicon leilled low carbon steels, collected in the refining treatment and continuous casting stages. Materials Research 7(4), pp. 1-9.

[3] Bigelow, L. \& Flemings, M. (1975). Sulfide inclusions in steel. Metallurgical and Materials Transactions, B 2(6), pp. 275-283.
[4] Payandel, Y. \& Mansour, S. (2007). Oxide inclusions at defferental steps of steel production. Journal of Iron and Steel Research International 5(14), pp. 39-46.

[5] Okhotskij, V.B. (2010). Non-metallic inclusions in steel in the process of deoxidation. Theory. Metallurgical and Mining Industry 2(4), pp. 260-261.

[6] Mihok, L', Janík, J., Kožár, O., Kratichvílová, J. \& Tóth, P. (1987). Study of distribution and comparision of nonmetallic inclusions in continuously cast slabs. BISI Translation Services (25524), 305.

[7] Mihok, L.(1987). Non - metallic inclusions in steel from BOF. Hutnicke listy 42(11), pp. 776-783.(Slovak).

[8] Gigovič-Gekič, A., Oruč, M., Vitez, I. \& Vujičič, B. (2009). Analyse and Research of non metallic inclusions for steel 100 Cr6. Metalurgija 48(1), pp. 29-32.

[9] Fernandes, M., Pires, J.C., Cheung, N. \& Garcia, A. (2003). Influence of refinning time on nonmetallic inclusions in a low-carbon, silicon-killed steel. Materials Characterization 51(5), pp. 301-308.

[10] Pickering, F.B. (1978). Non-metallic inclusions in steel. British Corrosion Journal 13(2), pp. 55-56.

[11] Šenberg, J. \& Martinil, L. (1999). Secondary metallurgy in the foundries of steel - 1. Part. Slévarenství XLVII $(6-7)$, pp. 180-184. (Czech).

[12] Pribulová, A., Futáš, P. \& Bureš, R. (2007). Influence of steel blowing with inert gas on steel cleanness. Acta Metallurgica Slovaca 13, Special Issue 4, pp. 133-136 (Slovak).

[13] Pan, S.M., Chiang, J.D. \& Hwang, W.S. (1997). Effects of gas injection condition on mixing efficiency in the ladle refining process. Journal of Materials Engineering and Performance 1(6), pp. 113-117.

[14] Chichkarev, E.A. (2010). Modelling the coagulation and removal of non.metallic inclusions during the injection of an inert gas into a melt. Metallurgist 54(3-4), pp. 236-243.

[15] Lisienko, V.G. at all. (2007). Refining steel in a ladle by inert gas and acoustic blow. Refractories and Industrial Ceramics 48(3), pp. 230-234. 